\title{
Apresentação
}

\section{Práticas e Políticas Culturais: Paradoxos e diálogos com a}

\section{tecnologia}

Cultural Practices and Policies: Paradoxes

and dialogues with the technology

\author{
Celeste Mira* e Marco Antônio Almeida ${ }^{*}$
}

* Livre-docente em Ciências Sociais pela PUC-SP, professora de Antropologia da PUC/SP, líder do GEPRACC

** Livre-docente em Ciências da Informação pela USP, professor e pesquisador da FFCLRP-USP e também do Programa de Pós-Graduação em Ciência da Informação da ECA/ USP.
O dossiê "Práticas e políticas culturais: paradoxos e diálogos com a tecnologia" reúne um conjunto de trabalhos originalmente apresentados no Primeiro Seminário anual dos grupos de pesquisa GEPRACC (Grupo de Estudos de Práticas Culturais Contemporâneas) e do PRACTIC (Grupo de Estudos de Práticas Culturais e Tecnologias de Informação e Comunicação), realizado em setembro de 2015 no Centro de Formação e Pesquisa do SESCSP.

O GEPRACC (Grupo de Estudos de Práticas Culturais Contemporâneas), criado em 2008, está vinculado à Pontifícia Universidade Católica de São Paulo (PUC-SP), com foco nas áreas de Ciências Sociais e coordenado pelas professoras Maria Celeste Mira e Mariza Werneck. Já o PRACTIC (Grupo de Estudos de Práticas Culturais e Tecnologias de Informação e Comunicação) foi fundado em 2012, vinculado à Universidade de São Paulo (USP), com atuação predominante nas áreas de Ciências Sociais Aplicadas e Ciência da Informação, e é coordenado pelos professores Marco Antônio de Almeida e Giulia Crippa. O seminário apresentou reflexões acerca de diversas dimensões das práticas culturais contemporâneas, tais como agentes e políticas culturais, usos e dinâmicas das tecnologias da informação, os sentidos da produção estético-cultural, e ainda as reconfigurações atuais do consumo cultural.

Abrem o dossiê dois textos que discutem a redefinição do "cultural" e de seus espaços de realização e exposição. O primeiro, "Sobre Conquistas e Tensões", de Lúcia Maciel Barbosa de Oliveira, discute as afinidades e tensões entre os universos da arte e da cultura, partindo de autores como Arendt e Agambem. A questão que permeia o texto é se há disposição para a arte hoje, para sua fruição, sua prática, considerando-se que as artes tornaram-se 
fenômeno de massa nas instituições que tradicionalmente as acolheram, aparentemente mais consumidas do que apropriadas. As narrativas que definiam as formas de representar o mundo, negando, excluindo e espetacularizando as diferenças a partir de perspectivas demarcadas, ganharam novos contornos que forçaram as fronteiras da representação, instituindo novos assuntos, novos atores, novas abordagens, outros olhares e sensibilidades. Na sequência, o texto de Giulia Crippa, "Museus e Exposição das Catástrofes: Políticas", aproveita o mote para discorrer acerca das maneiras pelas quais museus e memoriais lidam com o sentido de "catástrofe", como os museus de Hiroshima, de Minamoto e Auschwitz/Birkenau, discutindo a representação social de fatos históricos e da memória. Essa questão é problematizada pela discussão das modalidades de transformação dos lugares de memória em função do fenômeno do turismo de massa, complementada por ponderações sobre as representações do fim das instituições cuja função é representar a memória, principalmente museus.

Na sequência, outro subconjunto de textos irá discutir os impactos da tecnologia nas práticas e políticas culturais contemporâneas. No primeiro, "Política Cultural e Unidades Culturais de Infocomunicação", Marco Antônio de Almeida aborda a mediação cultural em espaços institucionais e os impactos proporcionados pelas Tecnologias de Informação e Comunicação (TICS) nesse processo. O texto analisa as políticas culturais em unidades de informação entendidas como espaços culturais, concentrando-se nas potencialidades de formação e de empoderamento cultural proporcionadas pelas políticas desenvolvidas por estas instituições. A partir dessa perspectiva, analisa os exemplos dos Pontos de Cultura, no Brasil, e o Sistema de Bibliotecas Públicas de Medellín, na Colômbia. O texto seguinte, "Transformações tecnológicas e perspectivas para a gestão democrática das políticas culturais”, de José Carlos Vaz, dialoga anteriormente com estas questões ao tecer reflexões acerca do processo da democratização da gestão cultural no Brasil, destacando as possibilidades do uso das Tecnologias da Informação e Comunicação (TICs) para promovê-la. Considera que, no contexto brasileiro pós-redemocratização, a pressão social por maior participação, transparência e controle social da gestão e das políticas públicas tem sido um importante eixo de transformações da gestão pública em vários setores. Nesse sentido, interroga se o Estado é capaz de estimular o surgimento e aproveitar iniciativas da própria sociedade que contribuam para democratização da gestão das políticas culturais

A construção de novas identidades e práticas culturais dá a tônica dos demais textos que compõem o dossiê. No artigo "Coletivos e redes culturais no Brasil contemporâneo: Notas sobre as relações entre cultura, economia e política na conjuntura neoliberal”, Miqueli Michetti analisa a ideologia e as práticas dos "coletivos culturais". Num contexto em que a cultura é concebida como "recurso", o âmbito cultural parece incorporar práticas e 
discursos do mundo corporativo, o qual, de sua parte, se alimenta da legitimidade que a esfera cultural confere a tais discursos e práticas. No seio desses coletivos, a fronteira entre vida pessoal e profissional é abolida, e os "trabalhadores culturais" se encontram em condições precárias. No entanto, a precariedade será aí conjugada em termos de "flexibilidade" e "liberdade". Diante disso, tais organizações assumem características corporativas, inclusive no que tange à disputa por "capital político". Fechando o dossiê, "Leitoras e Leituras: Acesso Orientado e Questões de Gênero", Larissa Akabochi de Carvalho retoma questões relativas às práticas identitárias e/ou de identificação, apontando que, historicamente, algumas leituras foram consideradas proibidas para o sexo feminino. Embora nem todas as mulheres se submetessem às proibições, a censura estava presente e dificultava a apropriação da informação. Com o desenvolvimento da tecnologia na segunda metade do século XX, facilitou-se o acesso. Porém, os meios de comunicação continuam a veicular informações marcadas pelas diferenciações de gênero. Através de uma análise quanto às indicações de leitura presentes nas revistas Claudia e Marie Claire e nos programas de televisão Saia Justa e Mais Você, a pesquisa aponta que ainda existe um acesso orientado de leitura para as mulheres, através de fontes de informação direcionadas ao público feminino.

A leitura do conjunto de textos que compõem o dossiê convida os leitores a percorrer uma trajetória que parte das discussões artísticas e estéticas, envereda pelas instituições e políticas culturais e deságua na constituição das identidades e nas práticas culturais do cotidiano. Trata-se de um mosaico significativo do território hoje ocupado pela reflexão social acerca da cultura e suas conexões com as tecnologias. 